\title{
Intraurban differentials of perinatal mortality: modeling for identifying priority areas
}

\author{
Diferenciais intraurbanos da mortalidade perinatal: modelagem para identificação de áreas prioritárias \\ Aspectos intraurbanos de la mortalidad perinatal: modelo para identificación de áreas prioritárias
}

\author{
Indianara Maria de Barros Canuto ${ }^{1}$ \\ Fábia Alexandra Pottes Alves ${ }^{1}$ (10) \\ Conceição Maria de Oliveira ${ }^{2,3}$ (1) \\ Paulo Germano de Frias ${ }^{2,4}$ (D) \\ Vilma Costa de Macêdo ${ }^{1}$ \\ Cristine Vieira do Bonfim ${ }^{1,5}$ (it)
}

1. Universidade Federal de Pernambuco.

Recife, PE, Brasil.

2. Secretaria de Saúde do Recife. Recife, PE, Brasil.

3. Centro Universitário Maurício de Nassau. Recife, PE, Brasil.

4. Instituto de Medicina Integral Professor

Fernando Figueira. Recife, PE, Brasil.

5. Fundação Joaquim Nabuco. Recife, PE, Brasil.

Corresponding author:

Indianara Maria de Barros Canuto.

E-mail:indianarabarros@hotmail.com.

Submitted on $06 / 10 / 2018$

Accepted on 10/15/2018.

DOI: 10.1590/2177-9465-EAN-2018-0166

\section{Abstract}

Objective: To analyze the intraurban spatial distribution of perinatal mortality, its avoidability, and relationship with socioeconomic indicators in Recife, Pernambuco, Brazil, in the period from 2013 to 2015. Method: An ecological study with data from the Information Systems on Mortality and Live Births and the Brazilian Institute of Geography and Statistics, using neighborhoods as the analysis unit. We elaborated an indicator of social deprivation formed by variables from the demographic census. We estimated the Kernel density of the deaths and calculated the Moran index of the perinatal mortality coefficients in the spatial analysis. We elaborated thematic maps of avoidable perinatal mortality and social deprivation. Results: The global statistical analysis of the mortality distribution indicated evidence of spatial aggregation. Moran's index was 0.18 . We found clusters of perinatal mortality in neighborhoods of the Central, North, Northwest, and South Regions. In the North, Northwest, Southwest, and South Regions we identified neighborhoods with greater social deprivation and avoidable mortality coefficients. The primary cause of death was of fetuses and newborns affected by hypertensive maternal disorders. Conclusion: We demonstrated intraurban differentials in perinatal mortality among neighborhoods. The stratification of the urban space according to the social deprivation indicator presented a relation with the perinatal mortality and its avoidability.

Keywords: Spatial Analysis; Health Level Disparities; Vital Statistics; Health Information Systems; Perinatal Mortality.

\section{Resumo}

Objetivo: Analisar a distribuição espacial intraurbana da mortalidade perinatal, sua evitabilidade e a relação com indicadores socioeconômicos no Recife, Pernambuco, no período entre 2013 e 2015. Método: Estudo ecológico com dados dos Sistemas de Informações sobre Mortalidade e Nascidos Vivos e do Instituto Brasileiro de Geografia e Estatística, utilizando bairros como unidade de análise. Elaborou-se um indicador de carência social formado por variáveis do censo demográfico. Estimou-se densidade de kernel dos óbitos, e calculou-se o índice de Moran dos coeficientes de mortalidade perinatal na análise espacial. Elaboraram-se mapas temáticos da mortalidade perinatal evitável e da carência social. Resultados: A análise estatística globa da distribuição da mortalidade apontou evidências de agregação espacial. O índice de Moran foi 0,18. Verificaram-se clusters da mortalidade perinatal em bairros das regiões Centro, Norte, Noroeste, Sudoeste e Sul. Com exceção do Centro, identificaramse bairros com maior carência social e coeficiente de mortalidade evitável em todas as regiões. A principal causa de morte fo feto e recém-nascido afetados por transtornos maternos hipertensivos. Conclusão: Mostraram-se diferenciais intraurbanos na mortalidade perinatal entre bairros. A estratificação do espaço urbano, de acordo com o indicador de carência social, apresentou relação com a mortalidade perinatal e sua evitabilidade.

Palavras-chave: Análise Espacial; Disparidades nos Níveis de Saúde; Estatísticas Vitais; Sistemas de Informação em Saúde; Mortalidade Perinatal.

\section{RESUMEN}

Objetivo: Analizar la distribución espacial intra urbana de la mortalidad perinatal, la capacidad de su prevención yla relación con indicadores socioeconómicos en la ciudad de Recife, estado de Pernambuco, en el período entre 2013 y 2015. Método: Estudio ecológico con datos de losSistemas de Información sobre Mortalidad y Nacidos Vivos, y del Instituto Brasileño de Geografía y Estadística, utilizando barrios como unidad de análisis. Se elaboró un indicador de carencia social formado por variables del censo demográfico. Se estimó la densidad de Kernel de muertes yse calculó el índice de Moran de los coeficientes de mortalidad perinatal en el análisis espacial. Se elaboraron mapas temáticos de la mortalidad perinatal evitableyde la carencia social. Resultados: El análisis estadístico global de la distribuciónde la mortalidad mostró evidencias de agregación espacial. El índice de Moran fue de 0,18. Se encontraron clústers de mortalidad perinatal en barrios de las Regiones Centro, Norte, Noroeste y Sur. En las Regiones Norte, Noroeste, Sudoeste y Sur se identificaron barrios con mayor carencia social y coeficiente de mortalidad evitable. La principal causa de muerte fue feto y recién nacido afectados por trastornos hipertensivos durante el embarazo. Conclusión: Se observaron diferentes aspectos intraurbanos en la mortalidad perinatal entre barrios. La estratificación del espacio urbano de acuerdo con el indicador de carencia social presentó relación con la mortalidad perinata y la capacidad de su prevención.

Palabras clave: Análisis Espacial; Disparidades en los Niveles de Salud; Estadísticas Vitales; Sistemas de Información en Salud; Mortalidad Perinatal. 


\section{INTRODUCTION}

Perinatal mortality, the period comprised between the 22nd week of pregnancy and the first seven days of life, reflects the access to health care and the quality of the assistance to the prenatal, the labor, and the newborn, constituting an expressive indicator of maternal and infant health. ${ }^{1}$

Around the world, perinatal deaths occur primarily in countries of low and medium income. ${ }^{1}$ In Brazil, between 2001 and 2015 , the perinatal mortality coefficient went from 22.3 deaths per thousand births to 17.4 (21.9\% reduction), with the South Region presenting the lowest coefficient and the Northeast, the highest: 15.4 and 21.2 deaths per thousand births, respectively. ${ }^{2}$ Approximately $47.6 \%$ of perinatal deaths occur due to avoidable causes. $^{3}$

Deaths considered avoidable are those unnecessary or potentially preventable by the effective action of health services. ${ }^{4}$ To classify the avoidability of the deaths, the List of Causes of Death Avoidable by Interventionsof the Brazilian Unified Health System (UHS) was elaborated, ${ }^{5}$ which contemplates the neonatal period, whose circumstances and etiologies are similar to the perinatal. ${ }^{6}$ This list classifies the causes of avoidable deaths in reducible by the following: immunoprevention actions; proper care to the pregnant women, labor, fetus, and newborn; adequate actions of diagnosis and treatment; appropriate health promotion actions linked to suitable health care actions. ${ }^{5}$

To ensure interventions directed toward perinatal deaths, there are recommendations of its inclusion in international and national pacts. ${ }^{7}$ Such deals act as instruments capable of making the magnitude of mortality explicit, in addition to favoring the planning of actions oriented towards combating these deaths. ${ }^{7}$ The global health strategy for the woman, the child, and the adolescent upon incorporating the avoidability of perinatal deaths aggregated perspectives of advances regarding the recognition of its importance. ${ }^{8}$ However, in the Brazilian inter-federative pacts, the perinatal mortality coefficient is little included, thus compromising the visibility of the problem, almost always mentioned through academic productions. ${ }^{7}$

The difficulties for reducing mortality, especially in areas with precarious living conditions, are consequences of the invisibility of perinatal deaths, which, in general, although avoidable, remain secondary in the public policies of developing countries such as Brazil. ${ }^{7}$ The unequal distribution of such deaths in the territories may demonstrate the socioeconomic segregation among populational groups ${ }^{9}$ usually revealed by characteristics regarding income, education, occupation, race/skin color, gender, and housing or workplace conditions. ${ }^{10}$

Studies that show the magnitude of perinatal death, its avoidability and relation with social deprivation indicators in the intraurban space may unveil inequities among populational groups. ${ }^{11,12}$ The agglomerates of perinatal deaths and social deprivation may be identified through spatial analysis. ${ }^{11}$ The methods of visualization, exploratory analysis, or modeling of georeferenced data enable integrating epidemiological, socioeconomic, and environmental information without dissociating them from the geographic space, ${ }^{13}$ allowing the detection of risk factors and the identification of priority areas for the health sector interventions. ${ }^{11,13}$

Researches that stratify the urban agglomerates by social deprivation may favor the understanding of the relationship that exists among the socioeconomic and environmental conditions and perinatal mortality. When comparing such strata with the spatial distribution of the avoidable deaths, it is possible to contribute to the planning of public policies oriented towards the areas that require a higher priority so to reduce the iniquities. The objective of this study was to analyze the intraurban spatial distribution of perinatal mortality, its avoidability, and its relationship with socioeconomic indicators in Recife, Pernambuco, Brazil, in the period from 2013 to 2015 .

\section{METHODS}

This is an ecological study carried out in Recife, capital of the state of Pernambuco, in the Brazilian Northeast, which had $1,599,514$ inhabitants (2013) distributed among $218.5 \mathrm{~km},{ }^{2}$ with a heterogeneous occupation pattern in which highly valued areas coexist with others that present relevant structural problems. ${ }^{14}$ The 94 neighborhoods are arranged in six Political-Administrative Regions (PARs): 1-Center, 2-North, 3-Northeast, 4-West, 5-Southwest, and 6-South ${ }^{14}$ (Figure 1).

The analysis unit considered was the neighborhood. For calculating the perinatal mortality coefficients, we included all perinatal deaths (fetal and early neonatal) registered in the Mortality

Figure 1. Geographic localization of the municipality of Recife and its division by Political-Administrative Regions. Recife, 2013 to 2015. Source: Municipal Government of Recife. Recife (PE), 2014.

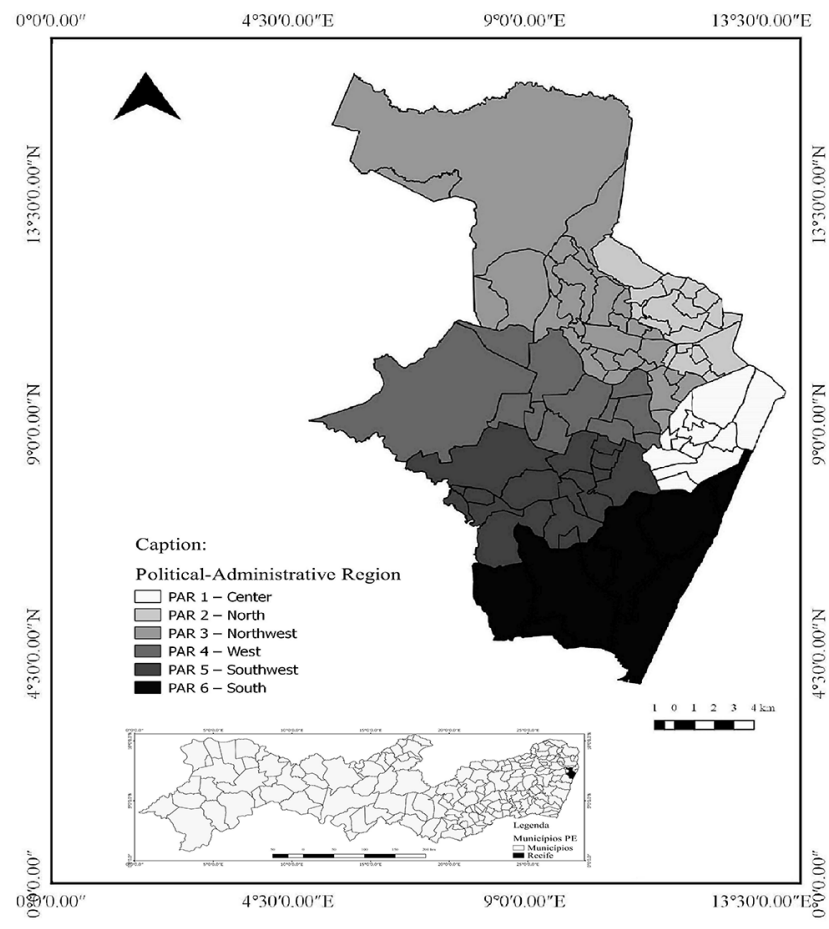


Information System (MIS) and the living births in the Living Birth Information System (LBIS) of residents of Recife, occurred from 2013 to 2015 . For the avoidable perinatal mortality coefficients per neighborhood, we used all the perinatal deaths with weights over $1500 \mathrm{~g}$ and underlying causes considered avoidable according to the criteria of the Brazilian List of Causes of Death Avoidable by Interventions of the UHS. ${ }^{2}$

To build the social deprivation indicator (SDI), we used the data from the 2010 Census of the Brazilian Institute of Geography and Statistics (IBGE, in Portuguese, Instituto Brasileiro de Geografia e Estatística). The indicator is composed of the following variables ${ }^{15}$ regarding the proportion of permanent private households that are: without a water supply linked to the general network; without garbage collection by a cleaning service; without an exclusive bathroom for residents or a toilet and sanitary exhaustion through the general sewage or pluvial network; without nominal monthly income; and with non-alphabetized responsible persons. We selected these indicators due to their relationship with the living condition of the population and with child and perinatal mortality. ${ }^{3}$

We calculate the SDI as the standardized average of economic and social variables. In each neighborhood, we verified the occurrence relative to the socioeconomic variables. The neighborhood with the most occurrences in a given variable received a score of one, while the one with the lowest incidence received zero. We calculated the scores of the other neighborhoods using the following formula: ${ }^{15}$

$$
\text { SCRneigh, } y v=(O C y v-O C \min , v) /(O C \max , v-O C \min , v) \text {, }
$$

where:

$$
\text { SCRneigh, } y v=\text { score of neighborhood " } y \text { " associated with }
$$
variable " $v$ ".

OCyv = ocurrence of variable " $v$ " in neighborhood" $y "$.

OCmin, $v=$ minimum ocurrence for variable " $v$ ", observed among all neighborhoods.

OCmax, $v=$ maximum occurrence for variable " $v$ ", observed among all neighborhoods.

Therefore, the SDI for each neighborhood is calculated as the mean of the already calculated scores:

$$
S D I y=\sum_{v}^{n} S C R n e i g h, v / n,
$$

where SDly is the social deprivation indicator of neighborhood " $y$ " and " $n$ " is the number of variables used in its calculation. The neighborhoods were grouped by tercile, which resulted in the strata: low, medium, and high.

In the spatial analysis, version 2.14.3 of program QGis ${ }^{\circledR}$ automatically located the geographic coordinates of the maternal residency points of the perinatal deaths through the georeferencing of the addresses with a search on the GoogleMaps ${ }^{\circledast}$ database. This technique consists in the attribution of geographic coordinates to the addresses, and, for its use, we performed the adaptation of the MIS database, the georeferencing itself, and the verification of its quality. The address of each event was searched in the MIS database and compared to those contained in the address database using version 2.14.3 of program QGis ${ }^{\oplus}$.

We applied the kernel estimation technique to promote the statistical smoothing and verify the influence of a point's density in the existence of others in close areas. ${ }^{17}$ We manually checked the points identified as geometric centers and approximate. To estimate the intensity of the event, we used a kernel with an adaptive radius of $1500 \mathrm{~m}$ and a quartic function. We used version 4.2.2 of program TerraView ${ }^{\circledR}$ to construct the thematic maps of the coefficients of perinatal mortality and avoidable perinatal of the SDI, grouped by tercile and distributed by neighborhood. We applied the spatial autocorrelation of the perinatal mortality coefficient, with the respective Moran values. The calculation of Moran's index indicates clusters with analogous risks for the event of interest, with its result being from -1 to $+1 .{ }^{11}$ Results close to zero indicate null autocorrelation among the areas and their neighbors. ${ }^{11}$ Positive results signal similarities among the neighboring microregions, while negative values suggest there are no similarities. ${ }^{11}$

The cartographic base of addresses and the digital meshes used are available on the website of the city hall of Recife (http://www.recife.pe.gov.br/ESIG/documentos/Informacao/ InformacaoManualArquivos.htm) and present a SIRGAS 2000/ UTM zone $25 \mathrm{~S}$ system of coordinate references.

This research obtained the approval of the Research Ethics Committee of the Joaquim Nabuco Foundation: Protocol no. 2.099.667 of June $5^{\text {th }}, 2017$.

\section{RESULTS}

In the period studied, the MIS registered 1,112 perinatal deaths of residents of Recife, with the perinatal mortality coefficient being of 15.80 deaths per thousand births. Figure $2 \mathrm{~A}$ shows spatial agglomerates of perinatal deaths with a high-intensity kernel in two neighborhoods of each of the following PARs: North (Água Fria and Alto Santa Terezinha), Northwest (Alto José do Pinho and Morro da Conceição), and South (Brasília Teimosa and Pina).

In the thematic map (Figure 2B), we found spatial agglomerates with higher values in three neighborhoods of the Center PAR, five of the North, eight of the Northwest, six of the Southwest, and two of the South. The spatial autocorrelation of the perinatal mortality coefficients was positive with priority areas (high-high clusters) made evident by the Box Map in the Center, North, Northwest, and South PARs (Figure 2C). In the Moran Map (Figure $2 \mathrm{D})$, areas with statistically significant autocorrelation $(\mathrm{I}=0.18$; $\mathrm{p}$-value $=0.02$ ) and high attention priority stood out, shown in darker shades, in two neighborhoods of the Center PAR (Cabanga and São José), one in the North (Fundão), three in the Northwest (Alto José Bonifácio, Brejo da Guabiraba, and Vasco da Gama), and two in the South (Pina and Brasília Teimosa). 
Figure 2. Kernel density map (A), thematic map (B), Box Map (C), and Moran Map (D) of the perinatal mortality coefficient by neighborhood. Recife, 2013 to 2015. Source: Health Secretariat of Recife. Recife (PE), 2013-2015.
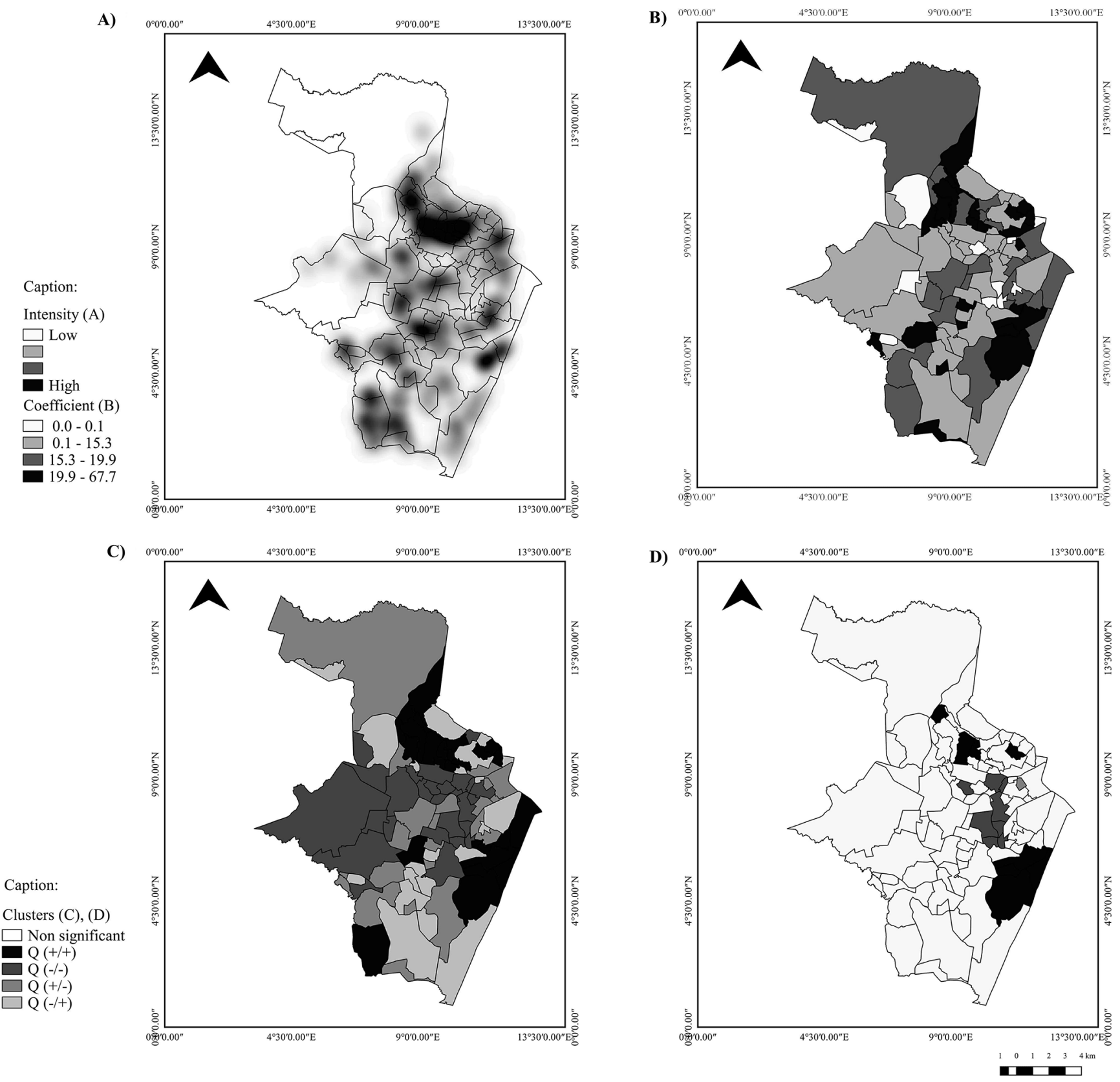

The perinatal deaths classifiable by the Brazilian List of Causes of Death Avoidable by Interventions of the UHS, after the separation by weight, presented avoidable causes ( $n=333$; $66.20 \%)$, ill-defined causes ( $n=64 ; 12.73 \%)$, and not clearly avoidable causes $(n=106 ; 21.07 \%)$.

In the thematic map of the social deprivation indicator (Figure 3A), one may visualize neighborhoods with high social deprivation in all the PARs. In the thematic map of the avoidable perinatal mortality coefficient (Figure 3B), we noticed spatial agglomerates with higher values in neighborhoods of all the PARs. For presenting high SDI and avoidable perinatal death coefficients, the neighborhoods that deserve emphasis are two in the North PAR (Cajueiro and Torreão), one in the Northwest (Morro da Conceição), and two in the Southwest (Jardim São Paulo and Totó) (Figures 3A and 3B). Table 1 shows that the highest avoidable mortality coefficients are in the strata with the worst social conditions.

The perinatal deaths could have been avoided especially 
Figure 3. Thematic maps of the social deprivation indicator per neighborhood (A) and the avoidable perinatal mortality coefficient (B). Recife, 2013 to 2015. Source: IBGE. Brazil, 2010; Secretariat of Health of Recife. Recife (PE), 2013-2015.

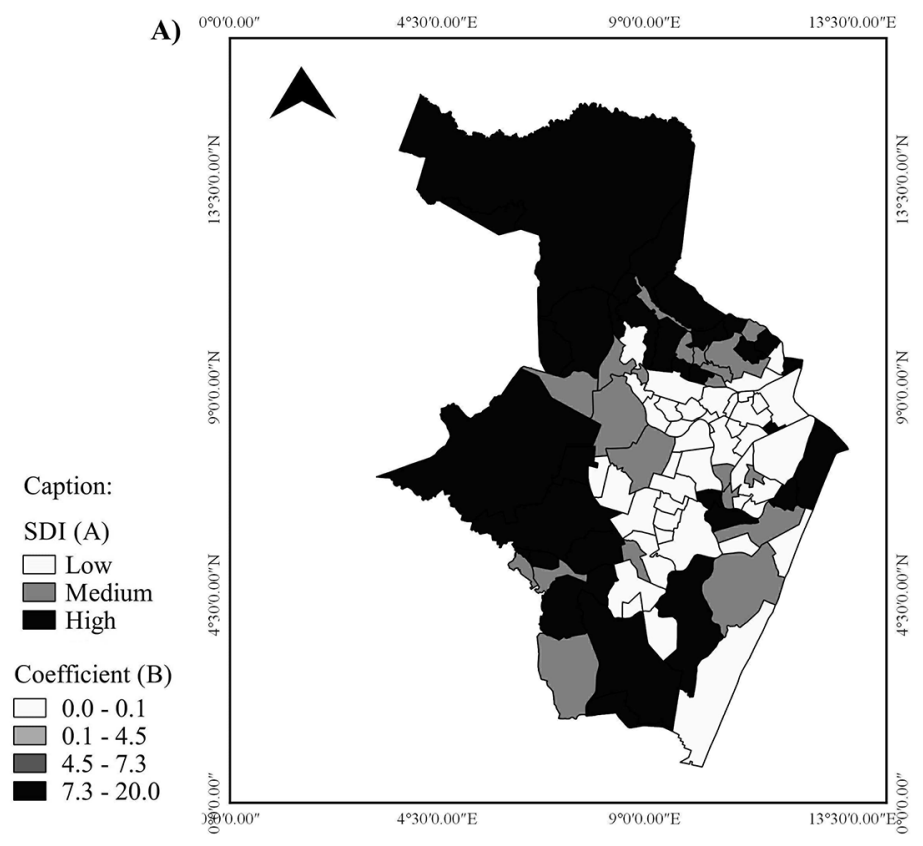

B)

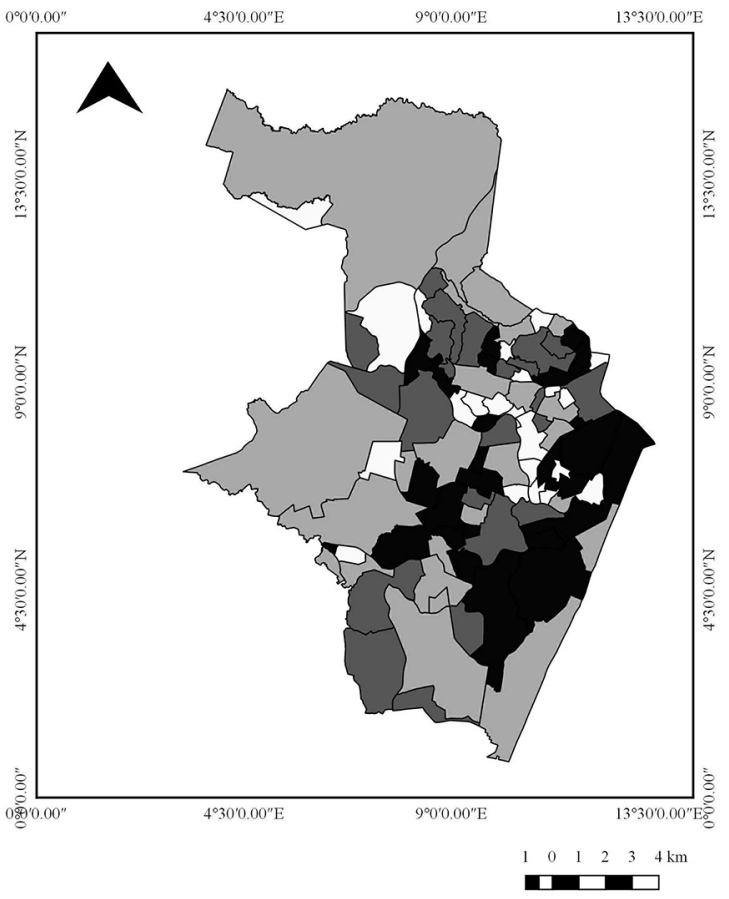

Table 1. Avoidable perinatal mortality coefficient according to the strata of social deprivation indicator. Recife, 2013-2015.

\begin{tabular}{lccc}
\hline Strata & $\begin{array}{c}\text { Avoidable } \\
\text { deaths }\end{array}$ & Births & Coefficient \\
\hline Low & 90 & 18377 & 4.89 \\
Medium & 121 & 23684 & 5.10 \\
High & 122 & 23927 & 5.09
\end{tabular}

Source: IBGE. Brazil, 2010.

with the adequate care to women during pregnancy $(n=164$; $49.25 \%$ ). The primary causes of death were the following: P00.0 - Fetus and newborn affected by hypertensive maternal disorders, which presented a higher proportion in the North PAR neighborhoods ( $n=13 ; 28.89 \%$ ); and P20.9 - Intrauterine hypoxia, with a higher value in the West PAR $(n=12 ; 19.35 \%)$. It is worth emphasizing the A50.0 - Congenital syphilis, which presented the highest proportion in the Northwest PAR $(n=7 ; 11.48 \%)$ (Table 2$)$.

\section{DISCUSSION}

The perinatal mortality coefficient of Recife from 2013 to 2015 was of 15.80 per thousand births, $10.1 \%$ below the national average (17.4). ${ }^{2}$ The spatial analysis of the perinatal mortality made explicit the differentials among the neighborhoods of the city, visualized in the kernel density map and the clusters with areas of priority attention without agglomerates in the Center, North,
Northwest, and South PARs, with such areas harboring pockets of concentrations of the municipality's poorer populational groups and robust social inequalities. ${ }^{18}$

Research carried out in the United States which thoroughly categorized the territory revealed segregations of health conditions on the geographic space, to aid the improvement of maternal and infant health conditions. ${ }^{19}$ Similarly, it is possible to signal areas with higher concentrations of deaths and indicate the presence of risk factors in specific localities, similar to the described in the literature. ${ }^{20}$

In Recife, the quality of the data on vital information considered reliable accompanied the improvement of the information systems of continuous record in Brazil, enabling to the public management a broad view of the locations with higher risks for mortality and collaborating for its combating and the reduction of inequalities. ${ }^{21}$ National and international research that value the use of spatial analysis techniques, signaling urban agglomerates without maps of points or of rates with a need of priority interventions are widely used due to their importance in subsidizing the management of health actions. ${ }^{11,22,23}$

This study, as another carried out in municipalities of the state of São Paulo, analyzed the spatial distribution of underlying causes of deaths. ${ }^{24}$ Regarding the classification of the avoidability of perinatal deaths, the highest proportion was considered avoidable, reducible especially with the proper care to women during pregnancy, a finding similar to previous ones regarding child mortality in Recife ${ }^{25,26}$ and other municipalities of the country. ${ }^{27}$ The predominant cause of death in all the PARs except the 
Table 2. Primary fundamental causes of avoidable perinatal death per Political-Administrative Region. Recife, 2013 to 2015.

\begin{tabular}{|c|c|c|c|c|c|c|c|c|c|c|c|c|}
\hline \multirow[b]{4}{*}{ Avoidable causes } & \multicolumn{12}{|c|}{ Political-administrative region } \\
\hline & \multirow{2}{*}{\multicolumn{2}{|c|}{$\begin{array}{l}\text { Center } \\
(n=26)\end{array}$}} & \multirow{2}{*}{\multicolumn{2}{|c|}{$\begin{array}{l}\text { North } \\
(n=45)\end{array}$}} & \multirow{2}{*}{\multicolumn{2}{|c|}{$\begin{array}{c}\text { Northwest } \\
(n=61)\end{array}$}} & \multirow{2}{*}{\multicolumn{2}{|c|}{$\begin{array}{c}\text { West } \\
(n=62)\end{array}$}} & \multirow{2}{*}{\multicolumn{2}{|c|}{$\begin{array}{c}\text { Southwest } \\
(n=62)\end{array}$}} & \multirow{2}{*}{\multicolumn{2}{|c|}{$\begin{array}{l}\text { South } \\
(n=77)\end{array}$}} \\
\hline & & & & & & & & & & & & \\
\hline & $\mathrm{n}$ & $\%$ & $\mathrm{n}$ & $\%$ & $\mathrm{n}$ & $\%$ & $n$ & $\%$ & $\mathrm{n}$ & $\%$ & $\mathrm{n}$ & $\%$ \\
\hline $\begin{array}{l}\text { Reducible by adequate care } \\
\text { to women during pregnancy* }\end{array}$ & 12 & 46.15 & 23 & 51.11 & 32 & 52.46 & 25 & 40.32 & 28 & 45.16 & 44 & 57.14 \\
\hline $\begin{array}{l}\text { P00.0 - Fetus and newborn } \\
\text { affected by hypertensive ma- } \\
\text { ternal disorders }\end{array}$ & 4 & 15.38 & 13 & 28.89 & 15 & 24.59 & 10 & 16.13 & 14 & 22.58 & 16 & 20.78 \\
\hline $\begin{array}{l}\text { A50.0 - Symptomatic congeni- } \\
\text { tal syphilis }\end{array}$ & 1 & 3.85 & 5 & 11.11 & 7 & 11.48 & 4 & 6.45 & 6 & 9.68 & 8 & 10.39 \\
\hline $\begin{array}{l}\text { Reducible by adequate care } \\
\text { to women during labor* }\end{array}$ & 7 & 26.92 & 17 & 37.78 & 21 & 34.43 & 27 & 43.55 & 22 & 35.48 & 22 & 28.57 \\
\hline $\begin{array}{l}\text { P02.1 - Fetus and newborn } \\
\text { affected by other forms of } \\
\text { displacement of the placenta } \\
\text { and hemorrhage }\end{array}$ & 1 & 3.85 & 4 & 8.89 & 1 & 1.64 & 4 & 6.45 & 5 & 8.06 & 7 & 9.09 \\
\hline $\begin{array}{l}\text { P20.9 - Unspecified intrauteri- } \\
\text { ne hypoxia }\end{array}$ & 4 & 15.38 & 7 & 15.56 & 10 & 16.39 & 12 & 19.35 & 12 & 19.35 & 7 & 9.09 \\
\hline $\begin{array}{l}\text { Reducible by adequate care } \\
\text { to the fetus and newborn* }\end{array}$ & 6 & 23.08 & 5 & 11.11 & 6 & 9.84 & 10 & 16.13 & 12 & 19.35 & 9 & 11.67 \\
\hline $\begin{array}{l}\text { P36.9 - Unspecified bacterial } \\
\text { septicemia of the newborn }\end{array}$ & 3 & 11.54 & 2 & 4.44 & 2 & 3.28 & 4 & 6.45 & 1 & 1.61 & 3 & 3.90 \\
\hline $\begin{array}{l}\text { P70.0 - Syndrome of the child } \\
\text { of a mother with gestational } \\
\text { diabetes }\end{array}$ & - & - & - & - & 2 & 3.28 & 3 & 4.84 & 3 & 4.48 & 3 & 3.90 \\
\hline $\begin{array}{l}\text { Reducible by adequate ac- } \\
\text { tions of diagnosis and treat- } \\
\text { ment* }\end{array}$ & - & - & - & - & 1 & 1.64 & - & - & - & - & - & - \\
\hline $\begin{array}{l}\text { Q90.9 - Unspecified Down } \\
\text { syndrome }\end{array}$ & - & - & - & - & 1 & 1.64 & - & - & - & - & - & - \\
\hline $\begin{array}{l}\text { Reducible by adequate ac- } \\
\text { tions of health promotion } \\
\text { linked to proper health care } \\
\text { actions* }\end{array}$ & 1 & 3.85 & - & - & 1 & 1.64 & - & - & - & - & 2 & 2.60 \\
\hline $\begin{array}{l}\text { W78.0 - Inhalation of gastric } \\
\text { content - residence }\end{array}$ & - & - & - & - & - & - & - & - & - & - & 1 & 1.30 \\
\hline $\begin{array}{l}\text { W78.9 - Inhalation of gastric } \\
\text { content - unspecified location }\end{array}$ & 1 & 3.85 & - & - & 1 & 1.64 & - & - & - & - & 1 & 1.30 \\
\hline
\end{tabular}

Source: Secretariat of Health of Recife. Recife (PE), 2013-2015.

* Malta DC, Sardinha LMV, Moura L, Lansky S, Leal MC, Szwarcwald CL et al. Update of the list of causes of death avoidable by interventions of Brazil's Unified Health System ${ }^{5}$. 
West was the fetus and newborn being affected by hypertensive maternal disorders, as described by other authors. ${ }^{25,26}$ The situation of congenital syphilis remains unacceptable, especially in the Northwest PAR, a result of the low effectivity in the care of pregnant women, particularly those more vulnerable. ${ }^{28}$

In the literature, most of the problems that result in perinatal deaths originate during pregnancy and are treatable when identified early. ${ }^{29}$ According to studies that report the Brazilian reality, when adequate, prenatal care enables the immunization of pregnant women, the early detection of morbidities and prematurity risk factors, ${ }^{30}$ the reduction of the vertical transmission of diseases, and the treatment of abnormalities, ${ }^{29}$ in addition to directing high-risk pregnant women to hospital units capable of providing intensive care to the potentially serious newborns increasing their chances of survival. ${ }^{31}$ Guidance is also provided about the care with the newborn in the post-partum. ${ }^{30}$

In this research, the avoidable perinatal mortality coefficient is higher in the strata with significant social deprivation indicators. Therefore, the social disparities favor the exposure of the more impoverished population to health risks. ${ }^{32}$ Furthermore, it makes opportune the access to the services and quality for privileged populational groups, characterizing the iniquities, as a Mexican study demonstrated. ${ }^{33}$ The spatial distribution of social deprivation may indicate areas with greater potentials of occurrence of adverse health outcomes ${ }^{15}$ and the agglomerates of avoidable deaths are capable of revealing iniquities. ${ }^{24}$

\section{CONCLUSION}

Upon detecting equivalences among spatial agglomerates of perinatal mortality, its avoidability, and indicators of social deprivation, this study identified inequalities and signaled areas that require priority attention to reduce deaths. The analysis unit employed imposes limits that may mask inequalities within neighborhoods considered of low priority. Likewise, it is not possible to infer that the indicators analyzed are homogeneously distributed in the areas deemed of priority. However, when incorporated to the actions of the health sector, the spatial analysis will be able to subsidize the decision making of the managers by indicating locations in the territory that present more significant health risks and need immediate allocation of resources.

\section{FINANCIAL SUPPORT}

Brazilian National Council of Scientific and Technological Development (CNPq) for funding the research with a scholarship of scientific initiation to the first author, from July of 2016 to June of 2017.

\section{REFERENCES}

1. Goldenberg RL, Mcclure EM. Maternal, fetal and neonatal mortality: lessons learned from historical changes in high income countries and their potential application to low-income countries. Maternal Health Neonato Perinatol [Internet].2015 Jan; [cited 2017 Oct 22]; 1:3. Available from: https:// mhnpjournal.biomedcentral.com/articles/10.1186/s40748-014-0004-z

2. Ministério da Saúde (BR). Departamento de Informática do SUS. Datasus Brasília (DF):2017. [cited 2017 Jul 26]. Available from: http://www.datasus. gov.br/DATASUS/index.php?acao=11\&id=33610

3. Barreto JOM, Nery IS, Mendes YMMB. Mortalidade perinatal: uma análise com enfoque na evitabitabilidade. Cogitare Enferm [Internet]. 2015 Jan/ Mar; [cited 2018 Aug 14]; 16(1):88-95. Available from: https://revistas.ufpr. br/cogitare/article/viewFile/21117/13943

4. Rutstein DD, Berenberg W, Chalmers TC, Child CG 3rd, Fishman AP, Perrin EB. Measuring the quality of medical care. A clinicalmethod. N Engl J Med [Internet]. 1976 Mar; [cited 2018 Aug 14]; 294(11):582-8. Available from: https://www.ncbi.nlm.nih.gov/pubmed/942758

5. Malta DC, Sardinha LMV, Moura L, Lansky S, Leal MC, Szwarcwald CL, et al. Atualização da lista de causas de mortes evitáveis por intervenções do Sistema Único de Saúde do Brasil. Epidemiol Serv Saúde [Internet] 2010 Apr/Jun; [cited 2018 Aug 14]; 19(2):173-6. Available from: http://www. producao.usp.br/bitstream/handle/BDPI/14517/art_MALTA_Atualizacao_ da_lista_de_causas_de_mortes_2010.pdf?sequence $=1$

6. Assis HM, Siviero PCL, Drumont EF, Machado CJ. Stillbirths from the perspective of preventable deaths: a preliminary analysis for the city of Belo Horizonte. Cad Saúde Coletiva [Internet]. 2014 Jul/Sep; [cited 2018 Aug 14]; 22(3):314-7. Available from: http://www.scielo.br/scielo. php?script=sci_arttext\&pid=S1414-462X2014000300314

7. Vanderlei LCM, Frias PG. Death surveillance as an instrument to reduce invisibility from social and assistance exclusion of women and children. Rev Bras Saúde Matern Infant [Internet]. 2017 Dec; [cited 2018 Apr 10]; 17(4):633-4. Available from: http://www.scielo.br/scielo.php?script=sci_ar ttext\&pid=S1519-38292017000400633

8. Cada Mulher. Cada Criança. Estratégia global para a saúde das mulheres crianças e dos adolescentes (2016-2030). 2016 [cited 2018 Aug 14]. Available from: http://www.everywomaneverychild.org/wp-content/ uploads/2017/10/EWEC_Global_Strategy_PT_inside_LogoOK2017_web. pdf

9. Rodrigues NC, Monteiro DL, Almeida AS, Barros MB, Pereira Neto A O'Dwyer G, et al. Temporal and spatial evolution of maternal and neonatal mortality rates in Brazil, 1997-2012. J Pediatr (Rio J) [Internet]. 2016 Dec [cited 2017 Oct 30]; 92(6):567-73. Available from: https://www.ncbi.nlm.nih. gov/pubmed/27234038

10. Fiorati RC, Arcêncio RA, Souza LB. Social inequalities and access to health: challenges for society and the nursing field. Rev Latino Am Enferm [Internet] 2016 Apr; [cited 2017 Nov 1]; 24:e2687. Available from: http://www.scielo. br/scielo.php?script=sci_arttext\&pid=S0104-11692016000100316\&lng= en\&tlng=en

11. Lara-Valencia F, Álvarez-Hernández G, Harlow SD, Denman C, GarcíaPérez $\mathrm{H}$. Vulnerabilidad socioambiental y mortalidad infantil em barrios de Hermosillo, Sonora. Salud Pública Méx [Internet]. 2012 Jul/Aug; [cited 2018 Jul 10]; 54(4):367-74. Available from: http://www.scielo.org.mx/scielo. php?script=sci_arttext\&pid=S0036-36342012000400006

12. Xiang K, Song D. Spatial Analysis of China Province-level Perinatal Mortality. Iran J Public Health [Internet]. 2016 May; [cited 2017 Nov 10]; 45(5):614-22. Available from: https://www.ncbi.nlm.nih.gov/pmc/articles/PMC4935705

13. Carlo WA, Travers CP. Maternal and neonatal mortality: time to act. J Pediatr [Internet]. 2016 Dec; [cited 2017 Dec 14]; 92(6):543-5. Available from: https://www.sciencedirect.com/science/article/pii/ S0021755716301012?via\%3Dihub 
14. Recife, Governo municipal. Secretaria de Saúde do Recife, Secretaria Executiva de Coordenação Geral, Gerência Geral de Planejamento. Plano Municipal de Saúde 2014 - 2017. Recife: Secretaria de Saúde; 2014. [Internet]. [cited 2018 Jan 15]. $1^{\text {a }}$ ed. 84 p. Available from: http://www2.recife.pe.gov.br/sites/default/files/plano_municipal_de_ saude_2015_revisado_menor.pdf

15. Bonfim C, Netto MJ, Pedroza D, Portugal JL, Medeiros Z. A socioenvironmental composite index as a tool for identifying urban areas at risk of lymphatic filariasis. Trop Med Int Health [Internet]. 2009 Aug; [cited 2017 Dec 14]; 14(8):877-84. Available from: https://www. ncbi.nlm.nih.gov/pubmed/19624474

16. Magalhães MAFM, Matos VP, Medronho RA. Evaluation of data of address in SINAN using locally georeferencing of tuberculosis cases by two methods in Rio de Janeiro. Cad Saúde Coletiva [Internet]. 2014 Apr/Jun; [cited 2017 Dec 20]; 22(2):192-9. Available from: http://www. scielo.br/scielo.php?script=sci_arttext\&pid=S1414-462X2014000200 $192 \& \operatorname{lng}=\mathrm{pt \&}$ tIng $=\mathrm{pt}$

17. Santos AMR, Rodrigues RAP, Santos CB, Caminiti GB. Geographic distribution of death samong elderly due to traffic accidents. Esc Anna Nery [Internet]. 2016 Mar; [cited $2017 \mathrm{Jul} 10$ ]; 20(1):130-7. Available from: http://www.scielo.br/pdf/ean/v20n1/1414-8145-ean-20-01-0130.pdf

18. Oliveira TG, Silveira Neto RM. Segregação residencial na cidade do Recife: um estudo da sua configuração. Rev Bras Est Reg Urb [Internet]. 2015; [cited 2018 Aug 16]; 9(1):71-92. Available from: https://www.revistaaber. org.br/rberu/article/view/115/151

19. MacQuillan EL, Curtis AB, Baker KM, Paul R, BackYO. Using GIS Mapping to Target Public Health Interventions: Examining Birth Outcomes Across GISTechniques. J Community Health [Internet]. 2017 Aug; [cited 2017 Sep 10]; 42(4):633-8. Available from: https://link.springer.com/article/10.1007/ s10900-016-0298-z

20. Leal MC, Bittencourt SDA, Torres RMC, Niquini RP, Souza Jr PRB. Determinants of infant mortality in the Jequitinhonha Valley and in the North and Northeast regions of Brazil. Rev Saúde Pública [Internet]. 2017 Mar; [cited 2018 Mar 23]; 51(12):1-9. Available from: http://www.scielo.br/ scielo.php?script=sci_arttext\&pid=S0034-89102017000100206

21. Frias PG, Szwarcwald CL, Morais Neto OL, Leal MC, Cortez-Escalante JJ, Souza Junior PRB, et al. Use of vital data to estimate mortality indicators in Brazil: from the active search for events to the development of methods. Cad Saúde Pública [Internet]. 2017 Apr; [cited 2018 Jan 30]; 33(3):1-3. Available from: http://www.scielo.br/scielo.php?script=sci_ arttext\&pid=S0102-311X2017000305014\&lng=pt\&tlng=pt

22. Banda M, Kazembe L, Lewycka S, King C, Phiri T, Masache G, et al. Spatial modelling of perinatal mortality in Mchinji, Malawi. Spat Spatiotemporal Epidemiol [Internet]. 2016 Feb; [cited 25 Jan 2018]; 16:50-8. Available from: https://www.sciencedirect.com/science/article/ pii/S1877584515000490?via\%3Dihub

23. Venâncio TS, Tuan TS, Vaz FPC, Nascimento LFC. Spatial Approach of Perinatal Mortality in São Paulo State, 2003-2012. Rev Bras Ginecol Obstet [Internet]. 2016 Oct; [cited 2018 Jan 22]; 38(10):492-8. Available from: https://www.thieme-connect.de/DOI/DOI?10.1055/s-0036-1594004
24. Nascimento LFC, Almeida MCS, Gomes CMS. Neonatal mortality and avoidable causes in the micro regionsof São Paulo state. Rev Bras Ginecol Obstet [Internet]. 2014 Jul; [cited 2018 Jul 16]; 29(7):303-9. Available from: http://www.scielo.br/pdf/rbgo/v36n7/0100-7203rbgo-36-07-00303.pdf

25. Oliveira CM, Bonfim CV, Guimarães MJB, Frias PG, Medeiros ZM Infant mortality: temporal trend and contribution of death surveillance. Acta Paul Enferm [Internet]. 2016 Jul; [cited 2018 Jul 16]; 29(3):28290. Available from: http://www.scielo.br/pdf/ape/v29n3/1982-0194ape-29-03-0282.pdf

26. Nascimento SG, Oliveira CM, Sposito V, Ferreira DKS, Bonfim CV. Infant mortality due to avoidable causes in a city in Northeastern Brazil. Bras Enferm [Internet]. 2014 Mar/Apr; [cited 2018 Jan 15]; 67(2):208-12. Available from: http://www.scielo.br/scielo.php?script=sci_arttext\&pi $\mathrm{d}=$ S0034-71672014000200208

27. Lisboa L, Abreu DMX, Lana AMQ, França EB. Infantmortality: leading avoidable causes in the central regionof Minas Gerais, Brazil, 19992011. Epidemiol. Serv Saúde [Internet]. 2015 Dec; [cited 2018 Aug 16]; 24(4):711-20. Available from: http://scielo.iec.gov.br/scielo. php?script=sci_arttext\&pid=S1679-49742015000400013

28. Macêdo VC, Lira PIC, Frias PG, Romaguera LMD, Caires SFF, Ximenes RAA. Risk factors for syphilis in women: case-control study. Rev Saúde Pública [Internet]. 2017 Aug; [cited 2018 Aug 16]; 51:78. Available from: https://www.ncbi.nlm.nih.gov/pmc/articles/PMC5559218/

29. Domingues RMSM, Viellas EF, Dias MAB, Torres JA, Theme-Filha MM, Gama SGN, et al. Adequacy of prenatal care according to maternal characteristics in Brazil. Rev Panam Salud Publica [Internet]. 2015 Mar [cited 2018 Jan 18]; 37:140-7. Available from: https://www.scielosp.org/ article/rpsp/2015.v37n3/140-147/

30. Lansky S, Friche AAL, Silva AAM, Campos D, Bittencourt DAS, Carvalho ML, et al. Birth in Brazil survey: neonatal mortality, pregnancy and childbirth quality of care. Cad Saúde Pública [Internet]. 2014; [cited 2017 May 13]; 30 Suppl 1:S1-15. Available from: http://www.scielo.br/ pdf/csp/v30s1/en_0102-311X-csp-30-s1-0192.pdf

31. Silva CF, Leite AJM, Almeida NMGS, Leon ACMP, Olofin I; Rede NorteNordeste de Saúde Perinatal. Factors associated with neonatal death in high-riskinfants: a multicenterstudy in High-Risk Neonatal Units in Northeast Brazil. Cad Saúde Pública [Internet]. 2014 Fev; [cited 2017 May 16]; 30(2):355-68. Available from: http://www.scielo.br/pdf/csp/ v30n2/0102-311X-csp-30-2-0355.pdf

32. Roos $\mathrm{N}$, von Xylander SR.Why do maternal and newborn deaths continue to occur? Best Pract Res Clin Obstet Gynaecol [Internet]. 2016 Oct [cited 2018 Feb 20];36:30-44. Available from: https://www.sciencedirect. com/science/article/pii/S152169341630030X?via\%3Dihub

33. Borde E, Akerman M, Morales BC, Hernández-Álvarez $M$, Guerra GG, Salgado de Snyder N. Capacidades de investigación sobre determinantes sociales de lasaluden Brasil, Colombia y México. Rev Fac Nac Salud Pública [Internet]. 2016; [cited 2018 Apr 12]; 34(3):33041. Available from: http://aprendeenlinea.udea.edu.co/revistas/index. $\mathrm{php/fnsp/article/view/25179}$ 